\title{
PENGEMBANGAN BAHAN AJAR TEMATIK-INTEGRATIF BERBASIS NILAI KARAKTER PEDULI LINGKUNGAN DAN TANGGUNG JAWAB
}

\author{
Yusinta Dwi Ariyani dan Muhammad Nur Wangid \\ Program Pascasarjana Universitas Negeri Yogyakarta \\ email: yusintada@gmail.com
}

\begin{abstract}
Abstrak: Penelitian ini bertujuan untuk menghasilkan bahan ajar tematik-integratif dengan tema "Lingkunganku Bersih dan Sehat" berbasis nilai karakter peduli lingkungan dan tanggung jawab yang layak dan efektif untuk peserta didik kelas I SDN 2 Padokan Bantul. Jenis penelitian ini adalah penelitian Research and Development (R \& D), yang terdiri dari 9 tahap, yaitu: (1) studi pendahuluan dan pengumpulan informasi; (2) perencanaan; (3) pengembangan produk awal; (4) uji coba awal; (5) revisi untuk menyusun produk utama; (6) uji lapangan utama; (7) revisi produk operasional; (8) uji lapangan operasional; dan (9) revisi produk akhir. Hasil penelitian menunjukkan bahwa bahan ajar yang dikembangkan layak dan efektif digunakan dalam pembelajaran. Kelayakan bahan ajar ditunjukkan dengan penilaian "baik" oleh ahli materi dengan skor 50, penilaian "sangat baik" oleh ahli media dengan skor 47 dan penilaian "baik" oleh guru dengan skor 75. Keefektifan dibuktikan dengan hasil uji-t $=-8,939$ yang menunjukkan bahwa kenaikan rerata skor signifikan dengan nilai $p$ sebesar 0,05 untuk karakter peduli lingkungan dan untuk karakter tanggung jawab hasil uji-t $=-6,254$ yang menunjukkan bahwa kenaikan rerata skor signifikan dengan nilai $p$ sebesar 0,05 .
\end{abstract}

Kata Kunci: bahan ajar, tematik-integratif, karakter peduli lingkungan, karakter tanggung jawab

\section{THE DEVELOPMENT OF INTEGRATED-THEMATIC TEACHING MATERIALS BASED ON CHARACTERS OF ENVIRONMENTAL CARE AND RESPONSIBILITY}

\begin{abstract}
This study aimed to produce an integrated-thematic teaching materials with the theme "my clean and healthy environment" based on characters of environmental care and responsibility which were appropriate and effective for the first grade students of SDN 2 Padokan in Bantul. This was a Research and Development (R \& D) study consisting of 9 stages, namely: (1) research and information collecting; (2) planning; (3) developing preliminary form of product; (4) preliminary field testing; (5) main product revision; (6) main field testing; (7) operational product revision; (8) operational field testing; and (9) final product revision. The results showed that the teaching materials developed were appropriate and effective to use in learning. The appropriateness of the teaching materials was assessed by the materials expert with "good" category with a score of 50, rated "very good" by the media experts with a score of 47 , and considered "good" by the teacher with a score of 75 . The effectiveness was shown by the results of the $t$-test $=-8.939$ which indicated that there was a significant increase in the mean score with $p$ value of 0.05 for the character of environmental care, and for the character of responsibility t-test results $=-6.254$ indicating that there was a significant increase in the mean score with $\mathrm{p}$ value of 0.05 .
\end{abstract}

Keywords: teaching materials, integrated-thematic, environmental care, responsibility

\section{PENDAHULUAN}

Pendidikan merupakan tulang punggung pembentukan karakter bangsa. Strategi pembentukan karakter bangsa melalui pendidikan dapat dilakukan dengan pembelajaran. Melalui pendidikan diharapkan dapat dihasilkan manusia yang berkualitas dan berkembang secara utuh sehingga da- pat berperan aktif dalam pembangunan bangsa. Melihat nilai strategis pendidikan, pemerintah melalui Kemendikbud terus menerus melakukan berbagai perubahan dan pembaharuan sistem pendidikan dengan tujuan agar generasi bangsa Indonesia menjadi bangsa yang cerdas sekaligus berkarakter. 
Pembentukan manusia yang berkarakter sebaiknya dimulai sejak dini, terutama diSekolah Dasar (SD) sebagai institusi yang paling dasar yang dapat menjadi tonggak awal dalam pembentukan karakter peserta didik. Pembentukan karakter sejak dini bertujuan agar nilai-nilai karakter yang ingin dibangun terekam dengan baik di benak peserta didik. Zuchdi (2011:xv) menyatakan bahwa tujuan utama pendidikan karakter adalah mewujudkan nilai-nilai luhur yang terkandung dalam Pancasila dalam pola pikir, pola rasa, dan pola perilaku sehari-hari dalam kehidupan masyarakat Indonesia secara keseluruhan. Tanpa karakter sebagai landasan bersikap dan berperilaku, besar kemungkinan rongga dada manusia dipenuhi hawa nafsu. Peran karakter yaitu ibarat nahkoda dalam sebuah kapal. Karakter adalah pengemudi yang akan menentukan arah benar salah ketika berlayar mengarungi lautan.

Mengingat karakter penting untuk membangun kepribadian seseorang dan bangsa, pemerhati dan pelaku pendidikan menawarkan berbagai solusi, salah satunya yaitu pendidikan karakter. Pendidikan karakter merupakan langkah strategis untuk menjadikan pribadi yang berkarakter. Hal ini diperkuat dengan pendapat Lickona (1991: 6), "Moral education is not a new idea. It is, in fact, as old as education itself. Down trough history, in countries all over the world, education has had two goals: to help young people become smart and to help them become good."

Pendidikan karakter begitu penting bagi pembentukan karakter yang baik. Tidak mungkin dapat dibentuk karakter yang baik, jika dalam proses pembelajaran hanya ditekankan pada kegiatan intelektual saja. Pengintegrasian pendidikan karakter pada setiap mata pelajaran menjadi sangat penting demi kesiapan peserta didik dalam menghadapi setiap permasalahan dalam kehidupannya.

Pendidikan karakter sebaiknya ditanamkan sejak dini terutama pada sekolah dasar yang merupakan tempat pendidikan yang utama bagi anak. Banyak fenomena yang kurang pantas dilihat sebagai anak yang berpendidikan. Misalnya, seringkali kita mendengar slogan-slogan di berbagai tempat terutama di sekolah, yang isinya mengajak kita untuk menjaga kebersihan lingkungan, akan tetapi slogan tadi tidak kita pedulikan. Slogan tadi fungsinya hanya seperti hiasan belaka tanpa ada isinya, padahal isi dari sebuah slogan sangat penting bagi kita. Banyak slogan yang mengajak untuk menjaga kebersihan, tetapi apa kenyataannya? Siswa masih sering membuang sampah sembarangan, seperti merobek-robek kertas dalam kelas dan memakan jajan di tempat A bungkusnya dibuang juga di tempat A. Padahal, di tempat tersebut telah disediakan tempat sampah. Hal ini menyebabkan sekolah menjadi kotor, kumuh, dan penuh dengan sampah. Di samping itu, sampah yang dibuang sembarangan tadi juga dapat mencemari lingkungan, baik di dalam kelas maupun di luar kelas dan juga dapat menyebabkan suasana belajar menjadi tidak nyaman.

Pembuangan sampah secara sembarangan mencerminkan hidup yang tidak sehat. Hal ini didukung oleh artikel yang berjudul "Mohon Ada Tempat Pembuangan Sampah di Gamping" (Tribun, 25 September 2013:5) yang menyebutkan masyarakat sulit diarahkan untuk membuang sampah pada tempatnya dan banyak yang membuang sampah di pinggir-pinggir jalan. Hal ini mencerminkan hidup yang tidak bersih dan kurang mencintai lingkungan. Selain kebersihan lingkungan, sebaiknya juga dijaga kebersihan dan kesehatan diri, seperti yang disarankan oleh Dinkes 
bahwa anak-anak dapat memilih jajanan yang sehat dan tidak berbahaya untuk dikonsumsi pada artikel Dinkes, "Sosialisasikan Jajanan Berbahaya" (Tribun, 20 September 2013:15). Oleh karena itu, siswa sebaiknya ikut menciptakan lingkungan sekolah yang bersih, rapi, indah, dan bersahaja, menanamkan kesadaran pada diri peserta didik bahwa sampah harus dibuang pada tempat sampah, menumbuhkan rasa tanggung jawab dalam diri bahwa kebersihan sekolah adalah tanggung jawab bersama, meningkatkan kebersihan diri pribadi anak mulai dari kebersihan badan, pakaian, dan alat-alat sekolah, ikut berpartisipasi dalam menjaga lingkungan tempat tinggal mereka. Jadi, penanaman nilai karakter peduli lingkungan dan tanggung jawab diperlukan bagi peserta didik, terutama di sekolah dasar agar karakter hidup sehat, menjaga kebersihan baik untuk diri sendiri dan lingkungan sekitar melekat pada diri peserta didik dan peserta didik diharapkan mempunyai kesadaran dari hati nuraninya sendiri akan tanggung jawabnya untuk menjaga kebersihan serta menjaga lingkungannya.

Upaya pemerintah dalam melakukan berbagai perubahan dan pembaharuan dalam sistem pendidikan, yaitu dengan menerapkan Kurikulum 2013 yang mulai diberlakukan pada bulan Juli 2013. Muhammad Nuh selaku Menteri Pendidikan dan Kebudayaan menyatakan bahwa orientasi pengembangan Kurikulum 2013 adalah tercapainya kompetensi yang berimbang antara sikap, keterampilan, dan pengetahuan, serta cara pembelajarannya yang holistik dan menyenangkan. Penerapan Kurikulum 2013 ini disajikan dalam model pembelajaran tematik-integratif. Depdiknas (2008:5) menyatakan bahwa pembelajaran tematik pada dasarnya adalah pembelajaran terpadu yang menggunakan tema untuk me- ngaitkan beberapa mata pelajaran sehingga dapat memberikan pengalaman bermakna pada peserta didik. Pembelajaran tematik diharapkan mampu melahirkan peserta didik yang kreatif, cerdas, dan inovatif. Rusman (2011:250) menyatakan bahwa amodel pembelajaran tematik memungkinkan peserta didik baik secara individual maupun kelompok aktif mencari, menggali, mengeksplorasi, dan menemukan konsep serta prinsip-prinsip holistik, autentik, dan berkesinambungan.

Perubahan kurikulum hampir mengubah seluruh sistem pembelajaran di jenjang SD. Dengan banyaknya buku pelajaran SD yang akan berubah, guru dituntut bisa mengembangkan bahan ajar sesuai dengan kebutuhan. Kenyataan di lapangan menggambarkan bahwa dalam pemahaman terhadap Kurikulum 2013 saja guru masih terbatas, apalagi menyusun bahan ajar untuk Kurikulum 2013 tersebut. Hal ini seperti dipaparkan pada artikel yang berjudul pemahaman Kurikulum 2013 masih lemah 124 instruktur tak lulus pelatihan (Kedaulatan Rakyat, 11 Juli 2013:8) bahwa pemahaman guru tentang Kurikulum 2013 masih lemah. Buktinya, dari 542 instruktur nasional yang telah dilatih, $23 \%$ di antaranya atau sebanyak 124 orang dinyatakan tidak lulus tes pascapelatihan. Materi pelatihan meliputi beberapa bidang kompetensi mulai dari pemahaman tentang konsep kurikulum, analisis materi ajar, model rancangan pembelajaran, hingga praktik pembelajaran terbimbing.

Berdasarkan uraian tersebut, ternyata banyak guru yang masih terbatas dalam pemahaman Kurikulum 2013. Banyak kompetensi yang harus dicapai untuk dinyatakan lulus. Selain itu, berdasarkan hasil evaluasi dan supervisi yang diselenggarakan oleh Ditjen. Pembinaan Sleman (2009), ditemukan bahwa masih banyak guru yang 
belum mampu mengembangkan bahan ajar secara mandiri. Guru kurang menyadari akan pentingnya menyusun bahan ajar yang sesuai dengan kebutuhan, manfaat bahan ajar dalam penyiapan bahan ajar dan pelaksanaan pembelajaran.

Guru hendaknya mengembangkan kemampuannya untuk membuat bahan ajar yang menarik. Hal ini diperkuat dengan pendapat Prastowo (2012:5) yang menyatakan bahwa kompetensi-kompetensi inti yang wajib dimiliki seorang guru di antaranya adalah mengembangkan kurikulum yang terkait dengan pengembangan yang diampu dan menyelenggarakan kegiatan pengembangan yang mendidik untuk kompetensi pedagogis, serta mengembangkan materi pembelajaran. Dari penjelasan tersebut jelas bahwa guru dituntut untuk mengembangkan dirinya dalam mengajar yang tampak masih kurang berkembang dalam pendidik saat ini. Dampak dari kurangnya pengembangan diri itu adalah banyak pendidik yang tidak mampu menyelenggarakan pembelajaran yang menarik dan menyenangkan. Keadaan ini salah satunya tidak terlepas dari kurang dikembangkannya bahan ajar yang inovatif. Para pendidik pada umumnya hanya menyediakan bahan ajar yang monoton, yang sudah tersedia dan tinggal pakai, serta tidak perlu harus bersusah payah membuatnya. Pada akhirnya yang menjadi korban adalah para peserta didik. Peserta didik akan merasa bosan mengikuti proses pembelajaran, sehingga pembelajaran menjadi tidak efektif dan efisien.

Para pendidik kurang mengembangkan kreativitasnya untuk merencanakan, menyiapkan, dan membuat bahan ajar secara matang yang kaya inovasi sehingga menarik bagi peserta didik. Hal ini tentu menjadi suatu masalah yang tidak sekedar bisa dipecahkan begitu saja, namun harus ada aksi nyata guna mengatasi persoalan tersebut. Salah satunya, para pendidik perlu membangun kreativitas mereka sendiri agar mampu membuat bahan ajar. Hal ini yang dapat menjadi salah satu langkah penting untuk dapat memajukan kualitas pendidikan.

Realitas pendidikan di lapangan menunjukkan, banyak pendidik yang masih menggunakan bahan ajar yang konvensional, yaitu bahan ajar yang tinggal pakai, tinggal beli, instan serta tanpa upaya merencanakan, menyiapkan, dan menyusun sendiri. Resiko sangat dimungkinkan dalam hal ini jika bahan ajar yang mereka pakai tidak kontekstual, tidak menarik, monoton, dan tidak sesuai dengan kebutuhan peserta didik. Bentuk-bentuk bahan ajar yang konvensional biasanya seperti bukubuku teks pelajaran yang diperjualbelikan di toko-toko, buku sumbangan dari Pemerintah atau LKS yang dibeli melalui para penyalur yang sering datang ke sekolahsekolah. Dengan adanya perubahan Kurikulum Tingkat Satuan Pendidikan (KTSP) menjadi Kurikulum 2013, banyak buku pelajaran SD yang akan berubah, dan guru dituntut dapat mengembangkan bahan ajar sesuai dengan kebutuhan.

Bahan ajar merupakan seperangkat materi yang disusun secara sistematis baik tertulis maupun tidak tertulis sehingga tercipta suasana yang memungkinkan peserta didik untuk belajar (Depdiknas, 2008:23). Bahan ajar yang menarik dan sesuai dengan karakteristik peserta didik akan menciptakan suatu lingkungan atau suasana yang memungkinkan peserta didik untuk belajar. Bertolak dari pemikiran tersebut, seyogyanya pembelajaran di SD membutuhkan bahan ajar yang tepat dalam menghadapi Kurikulum 2013 berbasis tematik-integratif. 
Pada artikel yang berjudul buku pelajaran SD dibagikan tiap tahun dan untuk siswa SMP dan SMA, buku dipinjamkan (Kompas, 11 Juli 2013:12) disebutkan banyak guru yang mengatakan masih bingung dengan cara mengajar tematik-integratif untuk peserta didik SD seperti disyaratkan dalam Kurikulum 2013. Oleh karena itu, perlu adanya bahan ajar yang berbasis tematik-integratif pada pelaksanaan Kurikulum 2013. Meskipun sudah tersedia bahan ajar untuk Kurikulum 2013, tetapi buku atau bahan ajar belum tersebar secara merata. Kepala Dinas Pendidikan DKI Jakarta, Taufik Yudi Mulyanto mengakui bahwa distribusi buku ajar Kurikulum 2013 belum tersebar seluruhnya (Suara Merdeka, 16 Juli 2013: 4). Didukung juga pada artikel yang berjudul Disdik tak Paksakan Kurikulum Baru (Tribun, 25 September 2013:11) yang menyatakan bahwa penerapan Kurikulum 2013 memang langsung dilakukan dengan bahan ajar yang masih kurang, tetapi pada artikel yang berjudul Buku Kurikulum 2013 Bebas Royalti (Tribun, 14 Juli 2013) disebutkan baru-baru ini Menteri Pendidikan Muhammad Nuh mengatakan bahwa buku-buku Kurikulum 2013 bebas diunduh (download) dan digandakan tanpa royalti. Buku ini bisa di-download di website www.belajar.kemdikbud.go.id. Tetapi buku Kurikulum 2013 ini memiliki beberapa kekurangan berdasarkan hasil analisis bu$\mathrm{ku}$ dan pendapat dari guru serta siswa sebagai pengguna buku Kurikulum 2013 dari Kemendikbud. Kekurangannya yaitu pengembangan nilai karakter pada peserta didik masih kurang terlihat, soal-soal latihan masih terlihat per mata pelajaran sehingga masih terpisah-pisah atau kurang holistik bagi peserta didik, tampilan masih seperti buku-buku pelajaran biasa sehingga kurang menarik peserta didik untuk belajar, dan tidak ada petunjuk penggunaan bahan ajar bagi peserta didik. Oleh karena itu, dibutuhkan bahan ajar yang berbasis Kurikulum 2013 yang mengintegrasikan pendidikan karakter.

Para pendidik hendaknya mampu mengembangkan bahan ajar secara mandiri sehingga tidak tergantung dengan bahan ajar yang sudah tersedia. Hal ini diperkuat dalam Pasal 8 Undang-Undang Nomor 14 Tahun 2005 tentang Guru dan Dosen yang menyebutkan bahwa guru wajib memiliki kualifikasi akademik, kompetensi, sertifikasi pendidik, sehat jasmani dan rohani, serta memiliki kemampuan untuk mewujudkan tujuan pendidikan nasional. Guru hendaknya bisa membuat bahan ajar secara mandiri yang lebih kreatif, inovatif, sesuai kurikulum, kebutuhan peserta didik, maupun perkembangan teknologi sehingga peserta didik akan terdorong untuk belajar lebih aktif. Bahan ajar tentunya tidak hanya mengolah secara kognitif saja, tetapi dituntut untuk memberikan pengembangan karakter pada peserta didik.

Berdasarkan hasil wawancara dengan salah satu guru di SDN 2 Padokan Bantul pada tanggal 4 Oktober 2013, diketahui bahwa kendala yang dihadapi dalam memanfaatkan bahan ajar Kurikulum 2013 dari Kemendikbud adalah waktu persiapan karena untuk memahami dan menerapkan Kurikulum 2013 ini sulit bagi guru. Jadi, dalam memanfaatkan bahan ajar pun guru harus lebih kreatif dan inovatif padahal buku Kurikulum 2013 hanya tersedia dari Kemendikbud saja. Guru sangat membutuhkan bahan ajar lain yang berbasis Kurikulum 2013 selain dari Kemendikbud. Karena bahan ajar dari Kemendikbud terbatas, maka guru masih memerlukan bahan ajar pendamping yang menarik minat siswa, mendorong untuk kreatif dan terdapat kegiatan-kegiatan yang lebih variatif. Seperti bahan ajar yang di dalamnya me- 
muat permainan-permainan yang mendidik yang sesuai dengan tema yang akan diajarkan. Dalam bahan ajar dari Kemendikbud hanya ada sedikit kegiatan yang menjadikan siswa untuk lebih kreatif.

Guru juga belum mampu mengembangkan bahan ajar secara mandiri, sehingga hanya mengandalkan bahan ajar dari Kemendikbud saja. Apalagi guru belum memahami sepenuhnya Kurikulum 2013, meskipun SD N 2 Padokan ini sudah menerapkan Kurikulum 2013. Berdasarkan latar belakang tersebut, penelitian ini bertujuan untuk menghasilkan bahan ajar berupa buku tematik-integratif berbasis character building, yaitu peduli lingkungan dan tanggung jawab pada peserta didik kelas I SD semester 2 dengan tema "Lingkunganku Bersih dan Sehat".

\section{METODE}

Jenis penelitian ini adalah penelitian dan pengembangan (Research and Development) yang diadopsi dari model pengembangan Borg \& Gall (1983: 775-776). Tahap penelitian ini hanya dilakukan sampai dengan tahap 9, yaitu: (1) studi pendahuluan dan pengumpulan informasi (research and information collecting); (2) perencanaan (planning); (3) pengembangan produk awal (developing preliminary form of product); (4) uji coba awal (preliminary field testing); (5) revisi untuk menyusun produk utama (main product revision); (6) uji lapangan utama (main field testing); (7) revisi hasil uji lapangan utama (operational product revision); (8) uji lapangan operasional (operational field testing); dan (9) revisi produk akhir (final product revision).

Teknik pengumpulan data yang digunakan dalam penelitian ini adalah observasi, penilaian produk, dan wawancara. Instrumen pengumpulan data menggunakan pedoman observasi karakter, penilaian produk bahan ajar untuk ahli materi dan ahli media serta menggunakan pedoman wawancara. Pedoman wawancara digunakan untuk mewawancarai guru dan peserta didik pada awal penelitian, sebelum, dan setelah menggunakan bahan ajar.

Penelitian ini dilakukan pada bulan Juni sampai dengan bulan Juli 2014 di SD N 2 Padokan Bantul. Subjek penelitiannya yaitu: (1) dua dosen ahli (ahli materi dan ahli media); (2) guru kelas I SD Negeri 2 Padokan; (3) para peserta didik kelas IC SD Negeri 2 Padokan sebanyak 3 peserta didik; (4) para peserta didik kelas IC SD Negeri 2 Padokan sebanyak 10 peserta didik; dan (5) para peserta didik kelas I SD Negeri 2 Padokan sebanyak 2 kelas. Kelas IA sebagai kelas kontrol sebanyak 30 peserta didik sedangkan kelas IB sebagai kelas eksperimen sebanyak 30 peserta didik.

Prosedur pengembangan pada penelitian ini menggunakan langkah satu sampai dengan sembilan dari model Borg \& Gall (1983:775-776). Pertama, studi pendahuluan dan pengumpulan informasi. Pada tahap ini dilakukan studi pustaka, survei lapangan, observasi SD dan wawancara dengan guru SD kelas I. Kedua perencanaan, pada tahap ini disusun format awal bahan ajar yang dikembangkan, yaitu dengan membuat rancangan-rancangan awal bahan ajar. Selain membuat rancangan awal bahan ajar, pada tahap perencanaan dilakukan penentuan Kompetensi Inti (KI) dan Kompetensi Dasar (KD), pemilihan tema, subtema yang diajarkan serta penyusuanan Rencana Pelaksanaan Pembelajaran (RPP). Ketiga, pengembangan produk awal. Pada tahap ini dilakukan pengembangan bahan ajar, pengembangan instrumen, dan validasi ahli. Keempat, uji coba awal. Pada tahap uji coba awal ini, setelah melalui tahap perencanaan dengan dilaksanakan validasi kepada ahli mengenai produk awal yang 
telah dibuat kemudian dilakukan revisi produk awal sesuai dengan yang disarankan oleh ahli. Tahap selanjutnya yaitu uji coba produk bahan ajar ke subjek pada skala kecil (terbatas). Kelima, revisi untuk menyusun produk utama. Pada tahap ini, setelah melakukan uji coba awal, hasilnya dianalisis. Setelah dianalisis, kemudian dilakukan revisi untuk menghasilkan produk yang akan digunakan pada uji coba lapangan. Keenam, uji lapangan utama. Tahap ini merupakan tahap penggunaan bahan ajar yang telah dikembangkan pada skala yang lebih luas. Ketujuh, revisi hasil uji lapangan utama. Pada tahap ini, setelah diuji cobakan pada skala lebih luas, hasilnya dianalisis kemudian dilakukan revisi untuk dapat menghasilkan produk yang lebih baik. Setelah dilakukan revisi dan menghasilkan produk yang lebih baik, kemudian digunakan pada uji lapangan operasional. Kedelapan, uji lapangan operasional. Pada tahap ini digunakan desain quasi eksperiment, yaitu nonequivalent-group pretest-postest design. Kesembilan, revisi produk akhir. Pada tahap ini, dilakukan revisi kembali hingga dihasilkan produk final atau produk terakhir. Revisi dilakukan berdasarkan saran yang diajukan terhadap hasil analisis data dari eksperimen pada tahap uji lapangan.

Penelitian ini menggunakan teknik analisis data kualitatif dan kuantitatif sesuai dengan prosedur pengembangan yang dilakukan. Untuk analisis data keefektifan produk menggunakan Uji-t untuk mengetahui sejauh mana keefektifan bahan ajar yang dihasilkan. Uji-t dipilih untuk membandingkan kedua mean dari kedua kelompok, yaitu kelompok eksperimen dan kelompok kontrol dengan rumus t-test. Keefektifan produk yang dihasilkan dapat dilihat dari rerata kemampuan akhir kedua kelas. Apabila nilai rata-rata kelas eksperi- men lebih tinggi dari rata-rata kelas kontrol maka pengembangan bahan ajar dikatakan efektif. Kriteria pengujiannya adalah sebagai berikut.

Ho = Tidak terdapat perbedaan antara kelas kontrol dengan kelas eksperimen.

$\mathrm{Ha}=$ Terdapat perbedaan antara kelas kontrol dengan kelas eksperimen.

Pengambilan keputusan dalam analisis uji-t ini dilakukan berdasarkan perbandingan nilai probabilitas atau nilai signifikansi, sebagai berikut.

Jika Probabilitas $>0,05$, maka Ho diterima

Jika Probabilitas < 0,05, maka Ho ditolak

\section{HASIL DAN PEMBAHASAN}

Hasil penelitian menunjukkan bahwa bahan ajar yang dikembangkan layak dan efektif digunakan dalam pembelajaran. Kelayakan dibuktikan dengan penilaian dari ahli materi, ahli media dan hasil diskusi dengan guru kelas 1 SD N 2 Padokan. Lembar penilaian produk bahan ajar dapat dilihat pada Tabel 1.

Tabel 1. Hasil Validasi dari Ahli Materi, Ahli Media dan Praktisi (Guru)

\begin{tabular}{clcc}
\hline No. & Ahli dan Guru & Penilaian & Kategori \\
\hline 1. & Ahli Materi & 50 & Baik \\
2. & Ahli Media & 47 & Sangat Baik \\
3. & Guru & 75 & Baik \\
\hline
\end{tabular}

Berdasarkan tabel di atas, bahan ajar yang dikembangkan dikatakan layak karena mendapatkan penilaian baik dari ahli materi dan guru bahkan mendapatkan penilaian sangat baik dari ahli media.

Untuk mengetahui keefektifan bahan ajar yang dikembangkan diperoleh dari wawancara terhadap peserta didik dan guru di akhir pembelajaran serta observasi karakter peserta didik. Wawancara dilakukan terhadap 30 orang peserta didik kelas 1B Sekolah Dasar Negeri 2 Padokan Bantul sebagai kelas eksperimen. Uji la- 
pangan operasional ini bertujuan untuk mengetahui secara langsung tanggapan peserta didik terhadap bahan ajar tematikintegratif dengan tema "Lingkunganku Bersih dan Sehat" berbasis nilai karakter peduli lingkungan dan tanggung jawab untuk peserta didik kelas I Sekolah Dasar Negeri 2 Padokan Bantul yang dikembangkan. Jenis wawancara yang digunakan adalah wawancara in dept interview. Wawancara ini dilakukan setelah akhir pembelajaran dan dilakukan secara bebas sehingga peserta didik tidak merasa diwawancarai. Bahasa yang digunakan adalah bahasa yang digunakan peserta didik sehari-hari dan mudah dipahami anak-anak.

Berdasarkan hasil wawancara yang dilakukan, 30 peserta didik berpendapat bahwa bahan ajar tematik-integratif dengan tema "Lingkunganku Bersih dan Sehat" berbasis nilai karakter peduli lingkungan dan tanggung jawab untuk peserta didik kelas 1 Sekolah Dasar Negeri 2 Padokan Bantul yang dikembangkan bagus dan menarik. Tampilan yang menarik karena warna yang dipergunakan serasi, materi mudah dipelajari, gambar memperjelas materi, sajian animasi yang menarik, serta tulisan yang lebih besar dibandingkan dengan bahan ajar yang sudah ada sehingga mudah untuk dibaca. Sajian tersebut membuat bahan ajar menjadi menarik dan disenangi oleh peserta didik. Ketertarikan peserta didik terhadap sumber belajar merupakan gejala yang sangat baik untuk menuju peningkatan belajar. Produk bahan ajar ini sangat memungkinkan peserta didik termotivasi untuk belajar secara aktif dan mandiri. Selain mudah digunakan, bahan ajar ini menurut para peserta didik tidak membosankan karena di dalamnya memuat materi yang sangat menarik mengenai karakter peduli lingkungan dan tanggung jawab dengan berbagai ilustrasi atau gambar-gambar yang menarik.

Hasil wawancara ini untuk melengkapi data yang telah didapatkan melalui observasi dan penilaian proses pembelajaran. Adapun hasilnya yaitu bahwa bahan ajar tematik-integratif dengan tema "Lingkunganku Bersih dan Sehat" berbasis nilai karakter peduli lingkungan dan tanggung jawab untuk peserta didik kelas 1 Sekolah Dasar Negeri 2 Padokan Bantul yang dikembangkan menarik bagi peserta didik dan memotivasi peserta didik sehingga bahan ajar yang dikembangkan efektif digunakan untuk peserta didik kelas 1 SD N 2 Padokan Bantul.

Wawancara dilakukan juga kepada guru kelas 1B Sekolah Dasar Negeri 2 Padokan Bantul sebagai kelas eksperimen setelah menggunakan bahan ajaryang dikembangkan. Tujuan uji lapangan operasional ini adalah untuk mengetahui secara langsung tanggapan guru terhadap bahan ajar tematik-integratif dengan tema "Lingkunganku Bersih dan Sehat" berbasis nilai karakter peduli lingkungan dan tanggung jawab untuk peserta didik kelas I Sekolah Dasar Negeri 2 Padokan Bantul yang dikembangkan. Jenis wawancara yang digunakan adalah wawancara in dept interview. Pertanyaan yang diajukan sesuai dengan pedoman pertanyaan wawancara yang telah disusun seperti pada uji lapangan utama.

Berdasarkan hasil wawancara yang dilakukan, guru berpendapat bahwa bahan ajar tematik-integratif dengan tema "Lingkunganku Bersih dan Sehat" berbasis nilai karakter peduli lingkungan dan tanggung jawab untuk peserta didik kelas 1 Sekolah Dasar Negeri 2 Padokan Bantul yang dikembangkan bagus dan menarik. Bahan ajar yang dikembangkan sudah sesuai dengan tuntutan Kurikulum 2013, bahan ajar yang dikembangkan juga dapat menginspirasi untuk membuat bahan ajar secara 
mandiri sehingga lebih inovatif dari bahan ajar Kemendikbud. Bahan ajar yang dikembangkan pun sudah memuat pembelajaran tematik integratif, bermuatan nilai-nilai karakter, terutama karakter yang menonjol dalam bahan ajar adalah karakter peduli lingkungan dan tanggung jawab, sudah kontekstual, sudah dapat mengaktifkan peserta didik, tampilan yang menarik karena warna yang dipergunakan serasi (colorfull) sesuai dengan keadaan peserta didik, materi mudah dipelajari, gambar memperjelas materi, sajian animasi yang menarik, serta tulisan yang lebih besar di bandingkan dengan bahan ajar yang sudah ada sehingga mudah untuk dibaca. Sajian tersebut membuat bahan ajar menjadi menarik dan disenangi oleh peserta didik. Ketertarikan peserta didik terhadap sumber belajar merupakan gejala yang sangat baik untuk menuju peningkatan belajar. Produk bahan ajar ini sangat memungkinkan peserta didik termotivasi untuk belajar secara aktif dan mandiri. Selain mudah digunakan, bahan ajar ini menurut guru tidak membosankan bagi peserta didik karena di dalamnya termuat materi yang sangat menarik mengenai karakter peduli lingkungan dan tanggung jawab dengan berbagai ilustrasi atau gambar-gambar yang menarik.

Ilustrasi memiliki banyak kegunaan sehingga bahan ajar yang dikembangkan banyak menggunakan ilustrasi-ilustrasi yang menarik. Forsyth, Jolliffe, dan Stevens (2004: 26) mengemukakan berbagai kegunakan ilustrasi, yaitu ilustrasi dapat digunakan untuk menggantikan paragraf teks dan memungkinkan peserta didik untuk mengingat informasi dengan jelas. Kegunaan ilustrasi, yaitu: (1) efisien dalam cara mereka menyajikan informasi; (2) sederhana dengan tidak ada rincian berlebihan; (3) mudah untuk membaca dan memiliki label yang jelas; (4) menyajikan pesan yang jelas;
(5) mampu melihat dengan jelas, yakni ukuran yang benar; dan (6) sesuai dengan pesan yang dilivered, misalnya, diagram, grafik, peta, skema, garis waktu, piktogram, atau kartun. Hal ini diperkuat oleh pendapat dari Sitepu (2012:151) bahwa fungsi ilustrasi buku teks pelajaran yaitu: (1) menimbulkan minat dan motivasi; (2) menarik dan mengarahkan perhatian; (3) membantu siswa memahami konsep yang sulit dijelaskan dengan kata-kata; (4) membantu siswa yang lambat membaca; dan (5) membantu mengingat lebih lama.

Penggunaan warna dalam ilustrasi buku teks pelajaran juga penting karena berfungsi untuk memberikan makna tertentu atau untuk estetika yang membuat daya tarik dan menimbulkan motivasi, menyampaikan fakta dan angka dengan cara yang berbeda, menekankan titik-titik tertentu, menampilkan hubungan dan ide-ide, bertindak sebagai visual, merangsang peserta didik dengan memvariasikan presentasi, membantu peserta didik mengingat sesuatu, menampilkan konsep verbal dalam bentuk visual, dan menampilkan kerja internal objek.

Hasil wawancara ini untuk melengkapi data yang telah didapatkan melalui observasi dan penilaian proses pembelajaran. Adapun hasilnya menyatakan bahwa bahan ajar tematik-integratif dengan tema "Lingkunganku Bersih dan Sehat" berbasis nilai karakter peduli lingkungan dan tanggung jawab untuk peserta didik kelas 1 Sekolah Dasar Negeri 2 Padokan

Bantul yang dikembangkan menarik dan dapat memotivasi peserta didik, sehingga bahan ajar yang dikembangkan efektif digunakan untuk peserta didik kelas 1 SD N 2 Padokan Bantul.

Bahan ajar tematik-integratif dengan tema berbasis nilai karakter peduli lingkungan dan tanggung jawab untuk peserta 
didik kelas I Sekolah Dasar Negeri 2 Padokan Bantul yang dikembangkan efektif digunakan dalam pembelajaran. Selain iru, berdasarkan hasil uji lapangan operasional dari analisis data menggunakan uji-t, menunjukkan adanya perbedaan yang signifykan antara kelas kontrol dengan kelas eksperimen dan kenaikan rerata skor setelah diberikan perlakuan yang berbeda. Kelas kontrol dalam pembelajaran menggunakan bahan ajar dari Kemendikbud, sedangkan kelas eksperimen dalam pembelajaran menggunakan bahan ajar yang telah dikembangkan.

Data hasil observasi karakter peduli lingkungan pada uji lapangan operasional yang menunjukkan adanya perbedaan antara kelas kontrol dengan kelas eksperimen. Kelas ekperimen mendapatkan rerata skor lebih tinggi dibanding kelas control, seperti yang dapat dilihat pada Tabel 1.

Tabel 1. Data Hasil Preobservation dan Postobservation Nilai Karakter Peduli Lingkungan pada Uji Lapangan Operasional

\begin{tabular}{lcc}
\hline \multicolumn{1}{c}{ Hasil } & \multicolumn{2}{c}{ Rata-rata Skor Aktual $(\mathrm{X})$} \\
\cline { 2 - 3 } & $\begin{array}{c}\text { Kelas } \\
\text { Kontrol }\end{array}$ & $\begin{array}{c}\text { Kelas } \\
\text { Eksperimen }\end{array}$ \\
\hline Preobservation & 26 & 26 \\
Postobservation & 27 & 30 \\
Peningkatan & 1 & 4 \\
Selisih Kelas & & \\
Kontrol dengan & & \\
Kelas & & \\
Eksperimen & & \\
\hline
\end{tabular}

Pada karakter peduli lingkungan kelas eksperimen memiliki rerata skor lebih tinggi daripada kelas kontrol. Hal ini sesuai dengan hasil analisis data menggunakan uji-t melalui program SPSS 17 untuk mengetahui keefektifan bahan ajar melalui observasi nilai karakter peduli lingkungan. Dengan membandingkan antara kelas kon- trol dan kelas eksperimen dihasilkan bahwa untuk hasil preobservation memiliki probabilitas atau signifikansi sebesar 0, 1000 dan $t$ sebesar 0,000. Signifikansi 0,1000 > 0,05 , sehingga Ho diterima. Itu artinya tidak terdapat perbedaan yang signifikan antara kelas kontrol dan kelas eksperimen. Hasil postobservation memiliki probabilitas atau signnifikansi sebesar 0,000 dan $t$ sebesar $-8,939$. Signifikansi $0,000<0,05$, jadi Ho ditolak. Itu artinya terdapat perbedaan yang signifikan antara kelas kontrol dan kelas eksperimen dan terjadi kenaikan rerata skor. Dengan demikian dapat disimpulkan bahwa bahan ajar yang dikembangkan efektif untuk mengembangkan nilai karakter peduli lingkungan.

Begitu juga pada karakter tanggung jawab, dihasilkan bahwa hasil preobservation memiliki probabilitas atau signifikansi sebesar 0,253 dan $t$ sebesar -1,154. Signifikansi 0,253 >0,05, sehingga Ho diterima. Itu artinya tidak terdapat perbedaan yang signifikan antara kelas kontrol dan kelas eksperimen. Hasil postobservation memiliki probabilitas atau signnifikansi sebesar 0,000 dan $\mathrm{t}$ sebesar $-6,254$. Signifikansi 0,000< 0,05 , sehingga Ho ditolak. Itu artinya terdapat perbedaan yang signifikan antara kelas kontrol dan kelas eksperimen dan terjadi kenaikan rerata skor. Dengan demikian, dapat disimpulkan bahwa bahan ajar yang dikembangkan efektif untuk mengembangkan nilai karakter tanggung jawab. Hal tersebut dapat dilihat pada Tabel 2.

Komponen lain yang digunakan untuk mengetahui keefektifan bahan ajar yang dikembangkan adalah dengan melakukan penilaian selama proses pembelajaran. Penilaian ini kemudian dianalisis sehingga diperoleh rerata skor. Hasil tersebut akan dibandingkan dengan Kriteria Ketuntasan Minimal (KKM) SD Negeri 2 Padokan Bantul, yaitu 75 . 
Tabel 2. Data Hasil Preobservation dan Postobservation Nilai Karakter Tanggung Jawab pada Uji Lapangan Operasional

\begin{tabular}{|c|c|c|}
\hline \multirow[t]{2}{*}{ Hasil } & \multicolumn{2}{|c|}{$\begin{array}{l}\text { Rata-rata Skor Aktual } \\
\qquad(X)\end{array}$} \\
\hline & Kelas & $\begin{array}{c}\text { Kelas } \\
\text { Eksperimen }\end{array}$ \\
\hline Preobservation & 41 & 42 \\
\hline Postobservation & 42 & 47 \\
\hline Peningkatan & 1 & 5 \\
\hline $\begin{array}{l}\text { Selisih Kelas Kontrol } \\
\text { dengan Kelas }\end{array}$ & & 4 \\
\hline Eksperimen & & \\
\hline
\end{tabular}

Semua peserta didik pada uji lapangan operasional masuk pada kriteria "tuntas" dalam mengikuti penilaian selama proses pembelajaran. Baik kelas kontrol maupun kelas eksperimen sama-sama tuntas dalam proses pembelajaran, akan tetapi setiap peserta didik di kelas eksperimen memiliki nilai yang jauh lebih tinggi. Hal ini membuktikan bahwa bahan ajar yang dikembangkan efektif untuk digunakan karena semua peserta didik berhasil tuntas mengerjakan soal yang diberikan selama proses pembelajaran menggunakan bahan ajar yang dikembangkan dan mendapatkan nilai lebih tinggi dibandingkan dengan kelas yang menggunakan bahan ajar dari Kemendikbud. Jadi, dapat disimpulkan bahwa bahan ajar yang dikembangkan dapat meningkatkan hasil belajar peserta didik.

Bahan ajar tematik-integratif berbasis nilai karakter peduli lingkungan dan tanggung jawab telah selesai dikembangkan. Bahan ajar ini telah selesai pula divalidasi oleh ahli materi, ahli media, dan diskusi bersama guru kelas I, serta telah mengikuti tahap-tahap dalam pengembangan.

Setelah melalui tahap validasi dari ahli materi, ahli media, dan diskusi dengan guru, bahan ajar yang dikembangkan ini diuji ke lapangan melalui tiga tahapan, ya- itu: uji coba awal, uji lapangan utama, dan uji lapangan operasional. Berdasarkan hasil penilaian ahli materi mendapatkan penilaian "baik" dengan skor 50 dan ahli media mendapatkan nilai "sangat baik" dengan skor 47 serta praktisi (guru) yang mendapatkan penilaian "baik" dengan skor 50 . Hal ini dapat dilihat dari penilaian ahli terhadap aspek-aspek penilaian kualitas bahan ajar. Aspek-aspek tersebut meliputi aspek kelayakan isi, aspek kebahasaan, aspek penyajian, dan aspek kegrafikaan. Berdasarkan hasil skor tiap-tiap aspek tersebut diketahui bahwa bahan ajar yang dikembangkan ini layak digunakan untuk peserta didik sekolah dasar kelas I semester 2.

Alasan tersebut sesuai dengan uraian dari Depdiknas (2008:28) yang menyebutkan mengenai kriteria penilaian bahan ajar yang hendaknya memenuhi aspek sebagai berikut. Aspek kelayakan isi meliputi: (1) kesesuaian dengan standar kompetensi, kompetensi dasar; (2) kesesuaian dengan perkembangan anak; (3) kesesuaian dengan kebutuhan bahan ajar; (4) kebenaran materi pembelajaran; (5) manfaat untuk penambahan wawasan; dan (6) kesesuaian dengan moral dan nilai-nilai sosial.

Aspek kebahasaan meliputi: (1) keterbacaan; (2) kejelasan informasi; (3) kesesuaian dengan kaidah bahasa indonesia yang baik dan benar; (4) pemanfaatan bahasa secara efektif dan efisien (jelas dan singkat). Aspek Penyajian meliputi: (1) kejelasan tujuan (indikator) yang ingin dicapai; (2) urutan sajian; (3) pemberian motivasi, daya tarik; (4) interaksi (pemberian stimulus dan respon); dan (5) kelengkapan informasi. Aspek kegrafikaan meliputi: (1) penggunaan font (jenis dan ukuran); (2) layout atau tata letak; (3) ilustrasi, gambar, foto; dan (4) desain tampilan.

Jika bahan ajar sudah memenuhi aspek-aspek seperti di atas, bahan ajar yang 
dikembangkan dikatakan layak untuk digunakan dalam pembelajaran. Jadi bahan ajar tematik-integratif dengan tema "Lingkunganku Bersih dan Sehat" berbasis nilai karakter peduli lingkungan dan tanggung jawab untuk peserta didik kelas I Sekolah Dasar Negeri 2 Padokan Bantul layak digunakan dalam pembelajaran.

Berdasarkan hasil wawancara dengan peserta didik dengan jumlah 43 anak, ada beberapa hal yang menurut mereka menjadi kelebihan dari produk bahan ajar yang dikembangkan. Di antaranya adalah tampilan yang menarik karena warna yang dipergunakan serasi, materi mudah dipelajari, gambar memperjelas materi, sajian ilustrasi gambar yang menarik, serta tulisan yang lebih besar dibandingkan dengan bahan ajar yang sudah ada sehingga mudah untuk dibaca. Sajian tersebut membuat bahan ajar menjadi menarik dan disenangi oleh peserta didik. Ketertarikan peserta didik terhadap sumber belajar merupakan gejala yang sangat baik untuk menuju peningkatan belajar.

Produk bahan ajar ini sangat memungkinkan peserta didik termotivasi untuk belajar secara aktif dan mandiri. Selain mudah digunakan, bahan ajar ini menurut para peserta didik tidak membosankan karena di dalamnya dimuat materi yang sangat menarik mengenai karakter peduli lingkungan dan tanggung jawab dengan berbagai ilustrasi atau gambar-gambar yang menarik. Bahan ajar yang dikembangkan ini dapat meningkatkan nilai karakter peduli lingkungan dan tanggung jawab serta hasil belajar peserta didik. Selain wawancara terhadap peserta didik, dilakukan juga wawancara dengan dua orang guru kelas IB dan IC. Berdasarkan hasil wawancara dengan kedua guru tersebut dapat disimpulkan bahwa bahan ajar yang dikembangkan sangat menarik dan memotivasi peser- ta didik serta dapat menjadi inspirasi bagi guru untuk membuat bahan ajar secara mandiri. Jadi, bahan ajar yang dikembangkan ini efektif digunakan dalam pembelajaran.

Alasan tersebut sesuai dengan yang dikemukakan oleh Kemdiknas (2010:12-20) bahwa pengembangan karakter dan budaya melalui tiga cara, yaitu: (1) melalui semua mata pelajaran; (2) pengembangan diri; dan (3) budaya sekolah. Salah satu dari ketiga cara untuk mengembangkan karakter tersebut adalah melalui mata pelajaran. Karakter peduli lingkungan dan tanggung jawab yang dikembangkan terintegrasi dalam mata pelajaran yang diajarkan di sekolah melalui bahan ajar yang dikembangkan.

Alasan lain seperti yang diungkapkan Lickona (Saptono, 2011:24) sekolah menjadi tempat terbaik bagi pendidikan karakter. Hal ini karena: (1) banyak keluarga (tradisional maupun nontradisional) yang tidak melaksanakan pendidikan karakter; (2) sekolah tidak hanya bertujuan membentukanak yang cerdas, tetapi juga anak yang baik; (3) kecerdasan seorang anak hanya bermakna manakala dilandasi dengan kebaikan; dan (4) membentuk anak didik agar berkarakter tangguh bukan sekadar tugas tambahan bagi guru, melainkan tanggung jawab yang melekat pada peran seorang guru.

Selain menggunakan bahan ajar yang mengandung karakter, bahan ajar untuk peserta didik sebaiknya dapat memotivasi untuk belajar. Seperti yang diungkapkan oleh Williams (2009: 208) bahwa bahan ajar yang menarik dapat memotivasi peserta didik. Pada penelitian ini peserta didik sudah termotivasi dengan bahan ajar yang menurutnya menarik sehingga peserta didik lebih bersemangat dalam mengikuti pembelajaran. Pembelajaran menjadi mudah diterima dan mudah terserap oleh 
peserta didik. Jadi, bahan ajar yang dikembangkan memang efektif digunakan dalam pembelajaran.

Bahan ajar tematik-integratif dengan tema "Lingkunganku Bersih dan Sehat" berbasis nilai karakter peduli lingkungan dan tanggung jawab untuk peserta didik kelas I ini dapat dijadikan alternatif pembelajaran untuk mengatasi keterbatasan guru dalam menyampaikan materi, memberikan pengetahuan tentang tanggung jawab dan kepedulian lingkungan pada anak-anak sehingga mampu mengaplikasikannya dalam pendidikan sehari-hari.

\section{PENUTUP}

Berdasarkan hasil penelitian yang telah diuraikan, dapat disimpulkan sebagai berikut. Pertama, berdasarkan penilaian dari ahli materi, bahan ajar tematik-integratif dengan tema "Lingkunganku Bersih dan Sehat" berbasis nilai karakter peduli lingkungan dan tanggung jawab untuk peserta didik kelas I Sekolah Dasar Negeri 2 Padokan Bantul layak digunakan dalam pembelajaran karena mendapatkan penilaian "baik" dengan skor 50 .

Kedua, berdasarkan penilaian dari ahli media, bahan ajar tematik-integratif dengan tema "Lingkunganku Bersih dan Sehat" berbasis nilai karakter peduli lingkungan dan tanggung jawab untuk peserta didik kelas I Sekolah Dasar Negeri 2 Padokan Bantul layak digunakan dalam pembelajaran mendapatkan penilaian "sangat baik" dengan skor 47.

Ketiga, berdasarkan hasil diskusi dengan guru kelas I, bahan ajar tematik-integratif dengan tema "Lingkunganku Bersih dan Sehat" berbasis nilai karakter peduli lingkungan dan tanggung jawab untuk peserta didik kelas I Sekolah Dasar Negeri 2 Padokan Bantul layak digunakan dalam pembelajaran karena mendapatkan penilaian "baik" dengan skor 75.

Keempat, berdasarkan hasil respons peserta didik melalui wawancara, bahan ajar tematik-integratif dengan tema "Lingkunganku Bersih dan Sehat" berbasis nilai karakter peduli lingkungan dan tanggung jawab untuk peserta didik kelas I Sekolah Dasar Negeri 2 Padokan Bantul yang dikembangkan baik, menarik, dan dapat memotivasi peserta didik dalam belajar serta dapat meningkatkan hasil belajar peserta didik sehingga layak digunakan dalam pembelajaran.

Kelima, bahan ajar tematik-integratif dengan tema "lingkunganku Bersih dan Sehat" berbasis nilai karakter peduli lingkungan dan tanggung jawab untuk peserta didik kelas I Sekolah Dasar Negeri 2 Padokan Bantul yang dikembangkan efektif digunakan dalam pembelajaran. Hasil uji lapangan dari analisis data menggunakan uji-t melalui program SPSS 17, menunjukan adanya perbedaan yang signifikan antara kelas kontrol dan kelas eksperimen dan kenaikan rerata skor setelah diberikan perlakuan yang berbeda. Kelas kontrol dalam pembelajaran menggunakan bahan ajar dari Kemendikbud, sedangkan kelas eksperimen dalam pembelajaran menggunakan bahan ajar yang telah dikembangkan. Hasilnya menunjukkkan bahwa uji-t = $-8,939$ yang artinya bahwa kenaikan rerata skor signifikan dengan nilai $p$ sebesar 0,05 untuk karakter peduli lingkungan dan untuk karakter tanggung jawab hasil uji-t $=$ $-6,254$ yang artinya bahwa kenaikan rerata skor signifikan dengan nilai $p$ sebesar 0,05.

Bahan ajar tematik-integratif dengan tema "Lingkunganku Bersih dan Sehat" berbasis nilai karakter peduli lingkungan dan tanggung jawab untuk peserta didik kelas I sekolah dasar yang telah dikembangkan disarankan dapat diterapkan dan 
digunakan secara maksimal oleh guru untuk mengembangkan karakter peserta didik SD. Bahan ajar tematik-integratif dengan tema "Lingkunganku Bersih dan Sehat" berbasis nilai karakter peduli lingkungan dan tanggung jawab untuk peserta didik kelas I sekolah dasar dapat digunakan sebagai contoh pembuatan bahan ajar yang lebih kreatif bagi guru sehingga guru mampu mengembangkan bahan ajar secara mandiri.

\section{DAFTAR PUSTAKA}

Brog, W.R. \& Gall, J.P. 1983. Educational Research an Introduction. New York: Longman.

Depdiknas. 2008. Strategi Pembelajaran yang Mengaktifkan Siswa. Jakarta: Depdiknas.

Forsyth, I., Jolliffe, A., \& Stevens, D. 2004. Practical Strategies for Teachers, Lecturers and Trainers (Vols. 2). New Delhi: Crest Publishing House.

Harian Kedaulatan Rakyat. 2013. Pemahaman Kurikulum 2013 Masih Lemah 124 Instruktur Tak Lulus Pelatihan. Edisi 11 Juli 2013, hal. 8.

Harian Kompas. 2013. Buku Pelajaran SD Dibagikan Tiap Tahun untuk Siswa SMP dan SMA, Buku Dipinjamkan. Edisi 11 Juli 2013, hal. 12.

Harian Suara Merdeka. 2013. Buku Kurikulum 2013 belum Terdistribusi Rata. http://www.suaramerdeka.com/v1 /index.php/read/cetak/2013/07/16 /231149/Buku-Kurikulum-3013-

Belum-Terdistribusi-Rata. Diakses tanggal 16 juli 2013 jam 21.00.

Harian Tribun. 2013. Buku Kurikulum 2013 Bebas Royalti. Edisi 14 Juli 2013, hal. 2.
Harian Tribun. 2013. Dinkes Sosialisasikan Jajanan Berbahaya. Edisi 20 September 2013, hal. 15.

Harian Tribun. 2013. Disdik Tak Paksakan Kurikulum Baru. Edisi 25 September 2013, hal. 11.

Harian Tribun. 2013. Mohon Ada Tempat Pembuangan Sampah di Gamping. Edisi 25 September 2013, hal. 5.

Lickona, T. 1991. Educating for Character How Our Schools Can Teach Respect and Responsibility. New York: Batam Book.

Prastowo, A. 2012. Panduan Kreatif Membuat Bahan Ajar Inovatif. Yogyakarta: Diva Press.

Puskur Kemdiknas. 2010. Pengembangan Pendidikan Budaya dan Karakter Bangsa Pedoman Sekolah. Jakarta: Pusat Kurikulum Kemdiknas.

Rusman. 2011. Model-model Pembelajaran Mengembangkan Profesionalisme Guru. Jakarta: Rajawali Pers.

Saptono. 2011. Dimensi-dimensi Pendidikan Karakter Wawasan, Strategi, dan Langkah Praktis. Jakarta: Esensi Erlangga Group.

Sitepu, B.P. 2012. Penulisan Buku Teks Pelajaran. Bandung: Remaja Rosdakarya.

Undang-Undang RI Nomor 14, Tahun 2005. tentang Guru dan Dosen.

Williams, K.C. 2009. Elementary Classroom Managementa Student-Centered Aproach to Leading and Learning. Los Angeles: Sage.

Zuchdi, D. 2011. Pendidikan Karakter dalam Perspektif Teori dan Praktik. Yogyakarta: UNY Press. 